\title{
PEMANFAATAN FASILITAS CLOUD COMPUTING UNTUK PEMBELAJARAN BAHASA ASING
}

\author{
J. Jamaluddin ${ }^{1}$, Roni J. Simamora ${ }^{2}$, M. Aritonang ${ }^{3}$ \\ ${ }^{1,2,3}$ DIII Manajemen Informatika - Universitas Methodist Indonesia \\ 'james_coleps@yahoo.com, ${ }^{2}$ ronimor4@gmail.com, ${ }^{3}$ tonang44@yahoo.com
}

\begin{abstract}
ABSTRAK
Cloud computing is a technology that uses internet services that use central servers will be virtual with the purpose of maintenance of data and applications. The existence of a clear cloud computing will lead to a change in how the information technology systems within an organization. This is because the concept of cloud computing through virtualization, standardization and other fundamental features can reduce the cost of information technology, simplifying information technology service management and accelerating service delivery. In general, cloud computing architecture consisting of (1) Infrastructure as a Service (IaaS) (2) Platform as a Service (PaaS) and (3) Software as a Service (SaaS). In this paper explicitly discusses the use of cloud computing applications of google translate for foreign language learning media.
\end{abstract}

Keywords: Information Technology, Cloud Computing, Google Translate.

\section{PENDAHULUAN}

Perkembangan teknologi informasi dan komunikasi sekarang ini telah membawa tren baru bagi pengguna layanan teknologi informasi, salah satunya adalah komputasi awan (cloud computing). Sebagai salah satu tren yang masih terus berkembang saat ini, teknologi cloud computing dihadirkan sebagai upaya untuk memungkinkan akses sumber daya dan aplikasi dari mana saja melalui jaringan internet, sehingga keterbatasan pemanfaatan infrastruktur teknologi informasi dan komunikasi yang sebelumnya ada telah dapat diatasi.

Selama beberapa tahun terakhir, munculnya cloud computing telah memberikan dampak yang luas biasa pada dunia industri teknologi informasi dan komunikasi. Banyak perusahaan besar seperti Google, Amazon, Apple, Cisco, Microsoft, IBM, dan Vmware menyediakan berbagai jenis platform cloud dengan cara yang berbeda-beda dalam hal pengiriman layanan ke penggunana akhir. Pengiriman layanan ini sepenuhnya berdasarkan pada model usaha mereka masing-masing.

Saat ini, cloud computing telah menyediakan berbagai jenis layanan seperti layanan perangkat keras (hardware), platform, infrastruktur dan aplikasi. Penggunaan dan pemanfaatan fasilitas cloud computing dapat dengan mudah dilakukan oleh pengguna akhir (end-user) tanpa harus mengetahui lokasi fisik dan konfigurasi dari sistem komputasi. Hal ini dapat terjadi karena sistem komputasi dari penyedia layanan cloud computing telah berhasil menyembunyikan berbagai kompleksitas dari manajemen infratruktur teknologi informasi dan komunikasi dari para pengguna.

Cloud computing telah menjadi sebuah solusi yang baik untuk meningkatkan kehandalan, memiliki kinerja yang tinggi, mengurangi biaya komputasi dan telah membuka peluang yang cukup besar untuk industri teknologi informasi dan komunikasi untuk meraih keuntungan yang lebih besar baik untuk penyedia layanan maupun bagi pengguna layanan.

Proses implementasi dari cloud computing membutuhkan pemahaman yang lebih baik. Pengetahuan tentang cloud computing dapat memberikan informasi yang lebih tentang pengertian, arsitektur dan model- model delivery service yang dimilikinya. Cloud computing juga sekaligus dapat meningkatkan kehandalan, keamanan dan pengendalian yang lebih baik, baik bagi penggunanya maupun penyedia layanannya. Saat sekarang ini sudah banyak fasilitas yang disediakan oleh penyedia layanan cloud computing seperti fasilitas untuk penyimpanan data, fasilitas surat elektronik, fasilitas pembuatan dokumen, lembar kerja ataupun dokumen presentasi, fasilitas bahasa pemrograman dan yang akan dibahas dalam jurnal ini adalah pemanfaatan fasilitas cloud computing untuk pembelajaran bahasa asing menggunakan aplikasi google translate.

Google translate (Google terjemahan) merupakan mesin penerjemah yang akan membantu menerjemahkan sebuah teks atau halaman web dari satu bahasa ke bahasa lain secara otomatis, sehingga pengguna terbantu ketika berusaha memahami isi sebuah halaman web. Google translate saat ini mampu menerjemahkan ke dalam lebih dari 50 bahasa, salah satunya adalah dari bahasa Indonesia ke bahasa Mandarin ataupun bahasa Inggris dan sebaliknya. Dalam tulisan ini penulis akan coba untuk memberikan uraian tentang pemanfaatan fasilitas google translate dalam pembelajaran bahasa asing terutama bahasa Mandarin dan bahasa Inggris.

\section{TINJAUAN PUSTAKA}

\section{Teknologi Cloud Computing}

Pada dunia teknologi informasi dan komunikasi para ahli telah banyak memberikan definisi atau pengertian tentang komputasi awan. Salah satu definisi cloud computing pada sebuah jurnal yang dipublikasikan oleh IEEE pada tahun 2008, cloud computing adalah sebuah paradigm dimana informasi secara permanen tersimpan di server di awan (internet) dan tersimpan secara sementara di computer pengguna, termasuk didalamnya adalah PC, desktop, computer tablet, notebook dan lain-lain ${ }^{[4]}$.

Teknologi cloud computing dapat didefinisikan secara sederhana sebagai sebuah perusahaan dengan pusat data yang menyediakan rental space storage. ${ }^{[4][6]}$ Maksudnya adalah teknologi cloud computing merupakan teknologiyang berbasiskan pada permintaan pengguna. Teknologi ini merupakan salah satu titik perubahan yang tidak hanya pada aplikasi perangkat 
lunak yang berbasis cloud computing tetapi juga pada platform, infrastrutur basis data maupun layanan semuanya berbasiskan cloud computing.

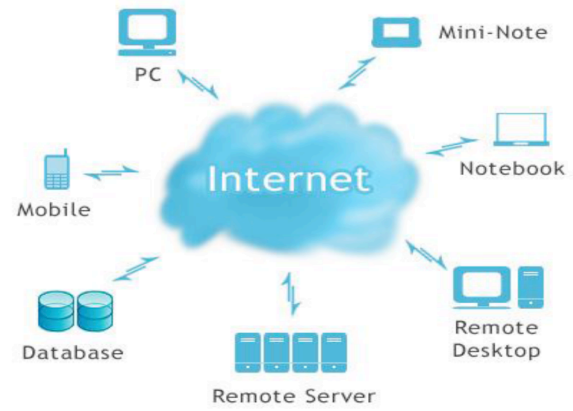

Gambar 1. Pemodelan Teknologi Cloud Computing

Kehadiran teknologi cloud computing awalnya memang hadir bagi kalangan industri. Ada beberapa alasan yang melatarbelakangi penerapan teknologi ini, antara lain :

(1) Ini adalah sebuah model layanan berbasis Internet untuk menampung sumberdaya sebuah perusahaan. Artinya sebuah perusahaan tak perlu lagi memiliki atau mendirikan infrastruktur lantaran sudah ada perusahaan lain yang menyediakan "penampung" di cloud alias Internet.

(2) Sebuah perusahaan tak perlu lagi mengalokasikan anggaran untuk pembelian dan perawatan infrastruktur dan software.

(3) Perusahaan pun tak perlu memiliki pengetahuan serta merekrut tenaga pakar dan tenaga pengontrol infra-struktur di "cloud" yang mendukung mereka.

National Institute of Standards and Technology (NIST), Information Technology Laboratory memberikan dua buah catatan mengenai pengertian cloud computing. Pertama, cloud computing masih merupakan paradigma yang berkembang. Definisi, kasus penggunaan, teknologi yang mendasari, masalah, risiko, dan manfaat akan terus disempurnakan melalui perdebatan baik oleh sektor publik maupun swasta. Definisi, atribut, dan karakteristik akan berkembang dan berubah dari waktu ke waktu. Kedua, industri cloud computing merupakan ekosistem besar dengan banyak model, vendor, dan pangsa pasar.

\section{Karakteristik Komputasi Awan}

NIST mengidentifikasi lima karakteristik penting dari komputasi awan (Mell \& Grance) sebagai berikut:

1. On-demand self-service. Pengguna dapat memesan dan mengelola layanan tanpa interaksi manusia dengan penyedia layanan, misalnya dengan mengguna-kan, sebuah portal web dan manajemen antarmuka. Pengadaan dan perleng-kapan layanan serta sumberdaya yang terkait terjadi secara otomatis pada penyedia.

2. Broad network access. Kemampuan yang tersedia melalui jaringan dan diakses melalui mekanisme standar, yang mengenalkan penggunaan berbagai platform (misalnya, telepon selular, laptop, dan PDA).
3. Resource pooling. Penyatuan sumberdaya komputasi yang dimiliki penyedia untuk melayani beberapa konsumen menggunakan model multi-penyewa, dengan sumberdaya fisik dan virtual yang berbeda, ditetapkan secara dinamis dan ditugaskan sesuai dengan permintaan konsumen. Ada rasa kemandirian lokasi bahwa pelanggan umumnya tidak memiliki kontrol atau pengetahuan atas keberadaan lokasi sumberdaya yang disediakan, tetapi ada kemungkinan dapat menentukan lokasi di tingkat yang lebih tinggi (misalnya, negara, negara bagian, atau datacenter). Contoh sumberdaya termasuk penyimpanan, pemrosesan, memori, bandwidth jaringan, dan mesin virtual.

4. Rapid elasticity. Kemampuan dapat dengan cepat dan elastis ditetapkan.

5. Measured Service. Sistem komputasi awan secara otomatis mengawasi dan mengoptimalkan penggunaan sumber-daya dengan memanfaatkan kemampu-an pengukuran (metering) pada beberapa tingkat yang sesuai dengan jenis layanan (misalnya, penyimpanan, pemrosesan, bandwidth, dan account pengguna aktif). Penggunaan sumber-daya dapat dipantau, dikendalikan, dan dilaporkan sebagai upaya memberikan transparansi bagi penyedia dan konsumen dari layanan yang digunakan.

Sedangkan tiga jenis model layanan dijelaskan oleh NIST (Mell dan Grance) sebagai berikut ${ }^{[5]}$ :

1. Cloud Software as a Service (SaaS). Kemampuan yang diberikan kepada konsumen untuk menggunakan aplikasi penyedia dapat beroperasi pada infrastruktur awan. Aplikasi dapat diakses dari berbagai perangkat klien melalui antarmuka seperti web browser (misalnya, email berbasis web). Konsumen tidak mengelola atau mengendalikan infrastruktur awan yang mendasari termasuk jaringan, server, sistem operasi, penyimpanan, atau bahkan kemampuan aplikasi individu, dengan kemungkinan pengecualian terbatas terhadap pengaturan konfigurasi aplikasi pengguna tertentu.

2. Cloud Platform as a Service (PaaS). Kemampuan yang diberikan kepada konsumen untuk menyebarkan aplikasi yang dibuat konsumen atau diperoleh ke infrastruktur komputasi awan menggunakan bahasa pemrograman dan peralatan yang didukung oleh provider. Konsumen tidak mengelola atau mengendalikan infrastruktur awan yang mendasari termasuk jaringan, server, sistem operasi, atau penyim-panan, namun memiliki kontrol atas aplikasi disebarkan dan memungkinkan aplikasi melakukan hosting konfigurasi.

3. Cloud Infrastructure as a Service (IaaS). Kemampuan yang diberikan kepada konsumen untuk memproses, menyim-pan, berjaringan, dan komputasi sumberdaya lain yang penting, dimana konsumen dapat menyebarkan dan menjalankan perangkat lunak secara bebas, dapat mencakup sistem operasi dan aplikasi. Konsumen tidak menge-lola atau mengendalikan infrastruktur awan yang mendasari tetapi memiliki kontrol atas sistem operasi, penyimpanan, aplikasi yang disebarkan, dan mungkin 
kontrol terbatas komponen jaringan yang pilih (misalnya, firewall host).

Model penyebaran komputasi awan menurut NIST terdiri dari empat model (Mell dan Grance, 2009) $)^{[5]}$, yaitu:

1. Private cloud. Swasta awan. Infrastruktur awan yang semata-mata dioperasikan bagi suatu organisasi. Ini mungkin dikelola oleh organisasi atau pihak ketiga dan mungkin ada pada on premis atau off premis.

2. Community cloud. Masyarakat awan. Infrastruktur awan digunakan secara bersama oleh beberapa organisasi dan mendukung komunitas tertentu yang telah berbagi concerns (misalnya, misi, persyaratan keamanan, kebijakan, dan pertimbangan kepatuhan). Ini mungkin dikelola oleh organisasi atau pihak ketiga dan mungkin ada pada on premis atau off premis.

3. Public cloud. Infrastruktur awan yang dibuat tersedia untuk umum atau kelompok industri besar dan dimiliki oleh sebuah organisasi yang menjual layanan awan.

Hybrid cloud. Hybrid awan. Infrastruktur awan merupakan komposisi dari dua atau lebih awan (swasta, komunitas, atau publik) yang masih entitas unik namun terikat bersama oleh standar atau kepemilikan teknologi yang menggunakan data dan portabilitas aplikasi (e.g., cloud bursting for load-balancing between clouds).

Secara garis besar definisi komputasi awan menurut NIST dapat digambarkan (Mell dan Grance) sebagai berikut:

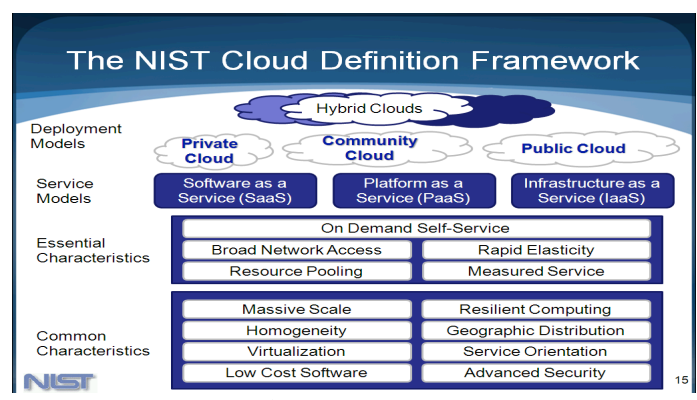

Gambar 2. Framework Cloud Computing menurut NIST

\section{Komponen Cloud Computing}

Ada tiga komponen dasar komputasi awan dalam topologi yang sederhana menurut Velte (2010) yaitu clients, datacenter, and distributed servers. Ketiga komponen dasar tersebut memiliki tujuan dan peranan yang spesifik dalam menjalankan operasi komputasi awan. Konsep ketiga komponen tersebut dapat digambarkan sebagai berikut :

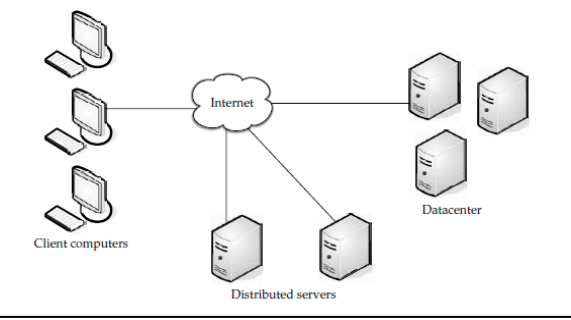

Gambar 3. Komponen Cloud Computing
Komponen lain dari cloud computing adalah Cloud Applications memanfaat-kan cloud computing dalam hal arsitektur software. Sehingga user tidak perlu menginstal dan menjalankan aplikasi dengan menggunakan komputer.

Cloud Platform merupakan layanan berupa platform komputasi yang berisi infrastruktur hardware dan software. Biasanya mempunyai aplikasi bisnis tertentu dan menggunakan layanan PaaS sebagai infrastruktur aplikasi bisnisnya. Cloud Storage melibatkan proses penyampaian penyimpanan data sebagai sebuah layanan. Cloud Infrastructure merupakan penyampaian infrastruktur komputasi sebagai sebuah layanan.

\section{Keuntungan Komputasi Awan}

Menurut sedikitnya ada tiga kategori utama dari keuntungan atau manfaat dari komputasi awan, yaitu ;

1. delivery of service (faster time-to-value and time-tomarket)

2. reduction of cost (CapEx vs. OpEx tradeoff and costs that are more competitive)

3. IT department transformation (focus on innovation vs. maintenance \& implementation)

\section{Google Translate}

Google pada awal diciptakan merupan alat atau mesin yang membantu menjelajahi internet didalam menemukan informasi atau website yang dicari oleh user. Mesin pencari (search engine) ini sangat bermanfaat karena banyaknya jumlah halaman web yang terdapat di internet. Google pertama kali dikembangkan pada tahun 1996 oleh dua mahasiswa Amerika Serikat yaitu Larry Page dan Sergey Brin. Saat ini Google merupakan mesin pencari terpopuler di dunia.

Mesin pencari Google dalam perkembangannya menyediakan berbagai fasilitas yang tidak sekedar hanya mencari halaman web, tetapi juga didalam pencarian gambar, video, buku, hasil penelitian, beasiswa dan juga dapat digunakan sebagai mesin penerjemah yang disebut google translate. Fasilitas google translate pertama kali dikembangkan oleh Google pada tahun 2007 dengan menggunakan sebuah sistem yang disebut SYSTRAN.

\section{PEMBAHASAN}

\section{Penggunaan Google Translate}

Penggunaan Google Translate sangatlah mudah, karena kita cukup terkoneksi dengan internet dan membuka halaman https://ranslate.google.co.id/ maka akan muncul tampilan situs seperti gambar berikut:

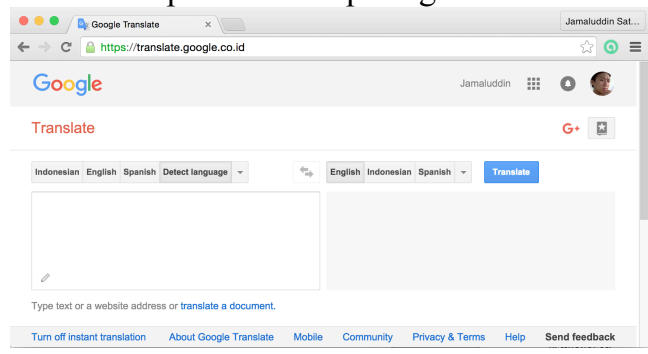

Gambar 4. Tampilan awal Google Translate 
Sampai saat ini google translate telah dapat menerjemahkan sebuah teks ke lebih dari 80 bahasa asing. Selain fasilitas terjemahan google translate juga menyediakan fasilitas pengucapan (spealling) untuk beberapa bahasa asing yang umum seperti bahasa Inggris, Mandarin, Jerman dan Prancis.

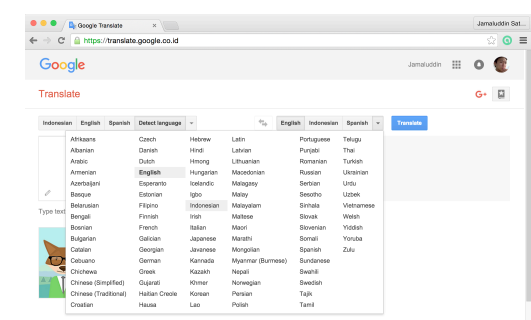

Gambar 5. Bahasa-bahasa yang disediakan Google Translate

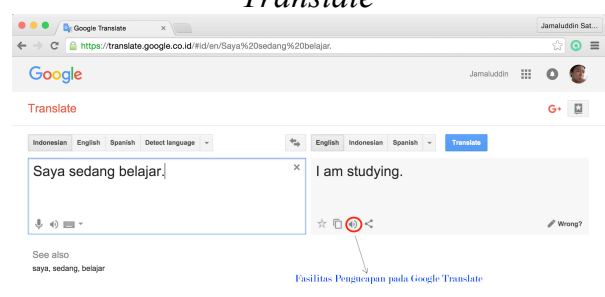

Gambar 6. Fasilitas Pengucapan pada Google Translate

Dengan lengkapnya fasilitas yang disediakan didalam Google Translate, selain sebagai mesin penerjemah yang biasa digunakan untuk menterjemahkan sebuah teks dari suatu bahasa ke bahasa lainnya Google Translate juga dapat dimanfaatkan sebagai media pembelajaran yang bagi pengguna internet yang masih belum pernah mengenal bahasa asing tertentu. Hal ini dikarenakan selain terdapat fasilitas pengucapan (spealling) pada bahasa Inggris, pada Google Translate juga terdapat fasilitas phonetically yakni fasilitas tulisan latin pada hasil terjemahan bahasa Mandarin.

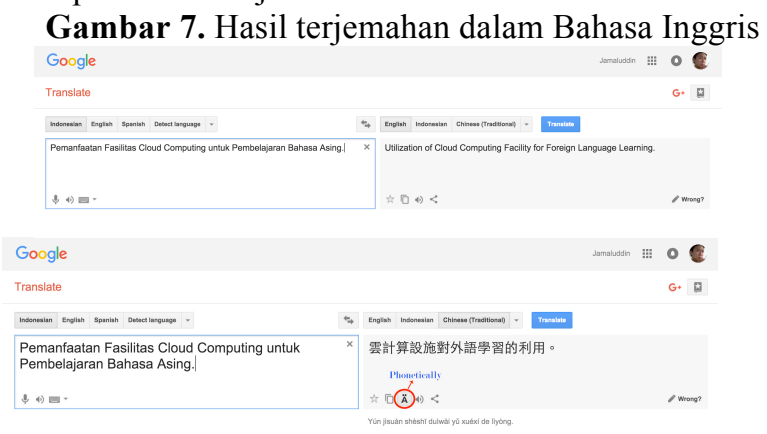

Gambar 8. Hasil terjemahan dalam Bahasa Mandarin dan cara pengucapannya (Phonetically)

\section{KESIMPULAN}

Pemanfaatan fasilitas Cloud Computing telah mempermudah setiap pengguna untuk memanfaatkan segala fasilitas yang disediakan di dalam Cloud Computing, salah satunya adalah penggunaan fasiltas penerjemah bahasa dengan aplikasi Google Translate. Selain dapat digunakan sebagai media penerjemah bahasa, Google Translate juga dapat dimanfaat sebagai media bagi kita didalam mempelajari bahasa asing seperti Bahasa Inggris atau Bahasa Mandarin.

\section{DAFTAR PUSTAKA}

[1] Ercana, T. (2010). "Effective Use of Cloud Computing in Educational Institutions". pada Procedia Social and Behavioral Sciences 2. p. 938942.

[2] Fajrillah \& Loly, H., (2014). "Implementasi Cloud Computing pada Sistem Informasi Manajemen Perguruan Tinggi Swasta", pada Seminar Nasional Teknologi Informasi dan Komunikasi (SNASTIKOM 2014) hal $1 \mid$ Cloud Computing. Medan: STTHarapan

[3] Foster, I., Y. Zhao, I. Raicu \& S. Lu, (2008). "Cloud computing and grid computing 360-degree compared", pada Proceedings of IEEE Grid Computing Environment Workshop. p. 1-10.

[4] Hayes, B., (2008). Cloud Computing. Communications of the ACM, 51 (7), 9-11.

[5] Jamaluddin, J. (2015). Pemanfaatan Fasilitas Cloud Computing untuk Pembuatan Dokumen dan Presentasi. Majalah Ilmiah METHODA, 5 (2), 6368.

[6] Mell, P. \& Grance, T., 2011, The NIST Definition of Cloud Computing, Gaithesburg: National Institute of Standards and Technology (NIST).

[7] Velte, A.T., Toby J. Velte \& Robert Elsenpeter. 2010, Cloud Computing: A Practical Approach. New York: McGraw-Hill.

[8] Zarlis, M., 2011, "Menelaah Janji-janji Cloud Computing dalam Bidang Teknologi Informasi". pada Prosiding Seminar Nasional Ke-3 Teknologi dan Rekayasa hal 1. Medan: FT UISU. 